\title{
Emitted and omitted discourses on diversity - time to admit privilege, race and power?
}

Ingvild Bjørkeng Haugen

Western Norway University of Applied Sciences, Norway

\begin{abstract}
Discourses on diversity in education have great importance for socially just educational practices. This article examines Norwegian teachers' reflections and language use on diversity, applying Critical Discourse Analysis [CDA]. The analysis indicates that some aspects of diversity are emitted while others are omitted, through two discourses. In the Adapted Education Discourse, diversity is connected to an individual level and aspects directly connected to learning. On the other hand, the Majority-Minority discourse is largely omitted from the material. Teachers seem to avoid and omit diversity categories connected to ethnicity and race. The discussion points to the possibilities of a socially just education system by dismantling privilege, race, and power.
\end{abstract}

Keywords: Critical Discourse Analysis; education; teacher

Recieved: April, 2020; Accepted: May, 2021; Published: June, 2021

\section{Introduction}

Measures to improve, change and reform the educational system to include and accommodate an increasingly diverse student population have been an ongoing process for over half a century (Hauge, 2014), through egalitarian, democratic, and social justice values like equity of opportunity, gender equality and inclusive education (e.g. Blossing et al., 2014). However, the latest teacher education reform is the first to set linguistic and cultural complexities at the core of all teaching (Skrefsrud \& Østberg, 2015). Increased emphasis on the interdisciplinarity of multicultural issues ${ }^{1}$

\footnotetext{
${ }^{1}$ A renewed and revised curriculum for the Knowledge Promotion Reform of 2006 [Kunnskapsløftet] as well as the Core Curriculum [Overordnet del] elaborate on the statutory clause [formålsparagrafen] of the Education Act. In this document, the curriculum is connected to a broader social and political context. The renewal consists of 'core elements' which should be overarching for all subjects. The Core Curriculum is also renewed, with 'identity and cultural diversity' amongst new core elements.
}

\footnotetext{
*Correspondence: Ingvild Bjørkeng Haugen, e-mail: Ingvild.Bjorkeng.Haugen@hvl.no
} 


\section{B. Haugen}

(NOU 2015: 8) is also found in compulsory education. This shift across educational levels can point to a broader understanding of both research and theoretical perspectives, including gender, sexuality, functional abilities, class, and social factors, to more traditional multicultural categories like culture and language (Røthing \& Bjørnestad, 2015). The concept of diversity ${ }^{2}$ has the last decade, been used increasingly to encompass all these factors in education.

Discourses of diversity have gained a strong foothold in Western educational policy and research. Although seemingly neutral and inclusive, the concept of diversity has been criticised for; its vagueness (Lund, 2018; Morken, 2009; Nyléhn \& Biseth, 2015), lack of conceptual clarity (Fylkesnes, 2018), and how it can mask differences and structural inequalities (Westrheim \& Hagatun, 2015). Borchgrevink and Brochman (2008) argue that diversity is used as a buzzword in education, with a concealing effect. This ambivalence is reinforced in empirical studies as well. Burner and Biseth (2016) found discrepancies between teachers and educational authorities' understandings of diversity. In addition, teacher educators and schoolteachers have different perceptions of diversity at the operational level (Burner et al., 2018). Blackmore (2006) suggests that diversity discourse(s) have replaced broader debates of equal opportunities and social justice, a shift Ahmed (2007) calls a strategical solution to an 'equity fatigue'.

This article aims to contribute insights into how teachers construct meaning of diversity by analysing teacher's language use through the following research question: Which discursive patterns emerge in teacher's reflections on diversity?

According to Biesta (2005), it is essential to critically examine the language used to constitute and construct meaning in education. How teachers construct meaning of diversity is crucial because it influences their work daily, and their conceptions shape both curricula and institutional practices (e.g. Eberly et al., 2007; Milner, 2010; Robinson \& Clardy, 2011). Simultaneously, teachers themselves are socialised into certain discursive practices through educational policy, practice, and experience, as well as societal and ideological currents (e.g. Gorski, 2011). This research aims not to criticise or assess teachers but to shed light on the language used when reflecting on diversity. In this article, diversity will be treated as a linguistic representation of a phenomenon and not as a word. In this sense, I can get insight into teachers' ideas, values and conceptions, or interpretative frames ${ }^{3}$ (Gullestad, 2002a).

Teachers' language use is analysed through Critical Discourse Analysis [CDA]. The analysis shows that some discourses are emitted while others are omitted. In this article, two discourses are displayed and discussed: The Adapted Education Discourse and the Majority-Minority Discourse. The analysis indicates that teachers mainly connect diversity to the individual level and aspects directly connected to

\footnotetext{
2 'Mangfold' in Norwegian

3 'Tolkningsrammer'
} 
learning. On the other hand, they seem to omit diversity categories connected to ethnicity and race.

\section{Discourse and critical perspectives on diversity}

Discourse is "a social practice that systematically forms the object of which it speaks" (Pihl, 2015, p. 47), and discourse-analytical approaches are preoccupied with language and its role in the construction of social reality (Willig, 2008). Theories affiliated with discourse are based on structural and post-structural philosophy of language, stating that language does not just mirror reality; linguistic representations create it (Jørgensen \& Phillips, 1999). Goldberg (1993a, p. 204) comments, "it is not just that the limits of our language limit our thoughts; the world we find ourselves in is one that we have helped to create, and this places constraints upon how we think the world anew". The dominant perspectives on education have discursive power because they set the educational agenda and draw up boundaries for what is possible to say and what is not (Møller, 2007).

Performing discourse analysis means inspecting established representations and the execution of power these representations justify (Gullestad, 2002a). In this way, CDA arguably have emancipatory objects. By showing that reality is not finitely given but a constant process of construction, reconstruction, and deconstruction, it offers possibilities of perspective expansions to change the established through "critical questioning of social life in moral and political terms, e.g., in terms of social justice and power" (Fairclough, 2003, p. 15). In other words, CDA can supply spaces, through evaluation and critique of social wrongs, in order to overcome them (Fairclough, 2013).

\section{Diversity and educational policy}

Like many other European countries, the minority population in Norway has increased in the latest decades, from 4\% in 1991 (Garthus-Niegel et al., 2015) to $14,7 \%$ (Statistics Norway, 2020). ${ }^{4}$ Educational policy and curriculum incentives have tried to reflect this demographical change, to create an education system that can respond appropriately to the varieties of needs in a diverse group of learners. Egalitarian, democratic, and social justice values like equity of opportunity, gender equality and inclusion, have a long tradition in the Norwegian educational system (Blossing et al., 2014; Sejersted, 2005). In this tradition, adapted education is seen as a cornerstone (Lillejord, 2003) to assure quality (Haug \& Bachmann, 2007).

Neo-liberalism and instrumentalist currents have also affected the last decades' educational policy (i. e. Hovdenak \& Stray, 2015; Telhaug et al., 2006), with expanding

\footnotetext{
${ }^{4}$ SSB uses the categories immigrants and children born of immigrant parents.
} 


\section{B. Haugen}

emphasis on students results and achievement levels (Skedsmo \& Mausethagen, 2017). The implementation of the Knowledge Promotion Reform, and especially White Paper Nr. 30. Culture for learning (Norwegian Ministry of Education and Research, 2004), marked a shift towards an individual perspective on students' prerequisites for learning. Haug and Bachman (2007) have argued that the quality aim of adapted education has led to increased attention to; processes and results at the cost of framework and structure, and the individual student and adapted education, to the expense of initiatives directed to the entire student mass.

Research has questioned the education system's ability to create equal opportunities (e.g., Chinga-Ramirez, 2017; Haugen, 2012; Hilt, 2015; Westrheim, 2004). Analysing the process from curriculum policy draft to the final version of the teacher education reform (2003), Skrefsrud (2014) found implications of a hidden assimilative pedagogy where the majority culture context is taken for granted as a natural frame of reference. Educational policy documents connected to the recent reforms in compulsory education and teacher education have both been critiqued for othering (Fylkesnes, 2019; Åberg, 2020).

\section{Method}

Thirteen semi-structured interviews (Kvale \& Brinkmann, 2009) with primary and lower secondary education teachers constitute the article's data. Principles of purposeful selection and snowball sampling were used for recruitment (Patton, 2002). Nine female and four male teachers with different subject background and work experience, working at twelve schools, were interviewed during the autumn of 2019. The schools differ in size, location, organisational structure, as well as minority population. The Norwegian Centre for Research Data (NSD) preapproved the study before the interviews, which lasted between 50 to 90 minutes. The teachers are (mainly) part of the majority population, making this research one of majority voices (Gullestad, 2002a). However, they were not asked to identify themselves in terms of race and ethnicity. Following is a description of the analytical process and methodological critique.

\section{Analytical steps}

Analytical steps were initiated with the interview guide's questions, which were constructed to invite reflections (Thagaard, 2003) concerning diversity. Three themes guided the conversation. Part one dealt with diversity, asking the teachers to describe their forms, what they understood by diversity in connection to education in general and their practice specifically. Diversity was intentionally left undefined as the term is often used in policy documents and educational settings without well-defined content. In discourse terms, diversity can be seen as a floating signifier (Laclau, 2005), or signs different discourses compete to fill with meaning and content (Jørgensen \& Phillips, 1999). Part two centred around reflections on teachers' educational 
intentions concerning diversity and dilemmas faced in their practices. Teachers were encouraged to describe specific instances, and how they were handled and reflected on at the time and in retrospect. Lastly addressed were the teachers' pedagogical competencies and life experiences. They were invited to reflect on how both affect their work and understanding of diversity.

This article's analytical steps do not set out to explore the whole of Fairclough's (2003) framework for CDA. Through an eclectic approach to CDA informed by Fairclough, a three-step analysis was conducted. Firstly, diversity was traced at the lexical level. What vocabulary was used, and what was the surrounding semantic chains of this vocabulary? This analytical step resulted in identifying ten typologies. Through this part of the analysis, various usage of the categories between the different teachers emerged. The first step indicated that some representations of diversity were explicit while others were implicit and/or less used by the teachers. The ten typologies are called diversity categories and marked in italics throughout the findings chapter. The findings are visualised as a continuum based on the forms of diversity teachers were most and least preoccupied with, from left to right in Model 1.

The second step was inspired by Fairclough's premise that "what is 'said' in a text always rests upon 'unsaid' assumptions" (2003, p. 11). This led to further investigation into the situated use (Wetherell et al., 2001) of the categories. Based on the continuum of categories, two discourse representations (Neumann, 2001) were identified. The emitted and omitted discourses dichotomies representing different discourse positions (Wodak \& Meyer, 2002).

Thirdly, the explanations in the discussion are connected to the macro-level, displaying some aspects of socio-historic conditions that govern the possibilities of what teachers can and cannot say about diversity (Fairclough, 1989, 1995, in Janks, 1997).

\section{Critique and ethical considerations}

Some methodological and ethical issues need addressing. Firstly, the validity of the study. Considering the post-structural premise of no one truth or reality in discourse analytical approaches (Hatch, 2002), validity will be understood as trustworthiness. The results should be found reasonable and possible to trace by other researchers based on transparency through the research process. Teachers were given information about the project and the analytical framework before the interviews were initiated and information that they could withdraw from the project at any time. Invitations to elaborate or delete parts of the transcribed interviews were sent via e-mail after the interviews. The analysis and findings were discussed with peers throughout the process.

Questions were constructed to provide the teachers space to elaborate and reflect through open-ended questions with follow-up questions. Their focus and understanding can be, as Lund (2018) found, due to the connection between teachers 


\section{B. Haugen}

understanding and reflections and the schools' profiles. This may have affected the findings, as they were not asked to elaborate on issues, they did not themselves raise, or the schools' respective profiles.

\section{Findings}

In this section, the result of the analysis will be presented. Firstly, the diversity categories found in teachers' lexical realisations are presented. Not all diversity categories will be discussed. I have chosen some that can represent the discursive patterns in the material. They are marked in italics throughout this section to ease the reading experience. Secondly, the discourses are presented, starting with the emitted Adapted Education Discourse, and finishing with the Majority-Minority Discourse.

\section{Diversity categories}

Teachers understand diversity predominantly as difference. Some teachers describe difference as the things children bring to school, illustrated through the backpack metaphor. One teacher reflects: "it is interesting that you do not see that heavy backpack until you know them well", pointing to invisible diversity categories only revealed over time and through the establishment of good relations. Teachers typically describe their forms as complex, and one teacher comments, "I like to say the form contains it all". The teachers in this study are explicitly occupied with their students' welfare and their ability to provide educational settings beneficial for their students, view diversity as a resource and the 'new normalcy'.

Through the analysis, ten diversity categories were found. All diversity categories were given attention through different manifestations, frequency, and emphasis by the teachers. A visualisation of the diversity categories is presented in Model I.
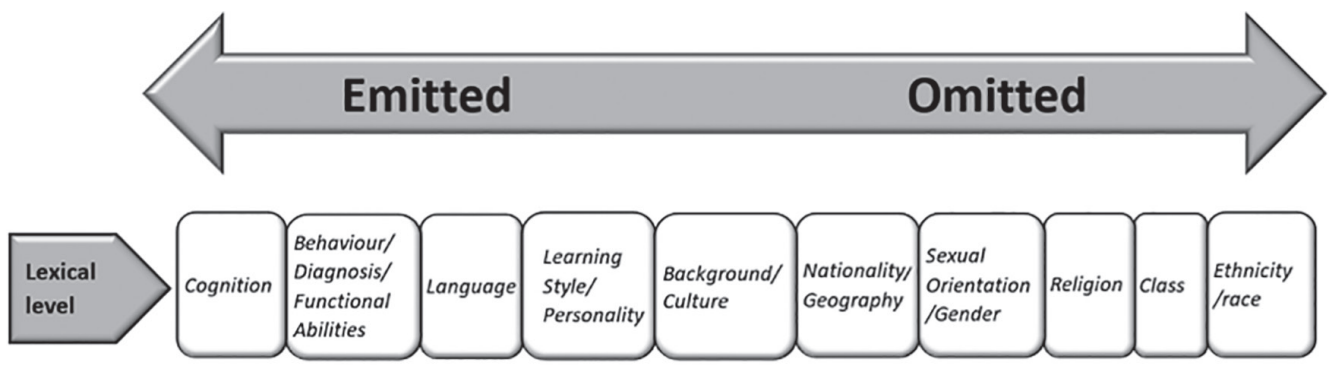

Model I. Emitted and omitted discourses lexical level.

The emphasis and manifestations of the lexical level resulted in the emerging pattern of two discourses, as shown in Model II. 


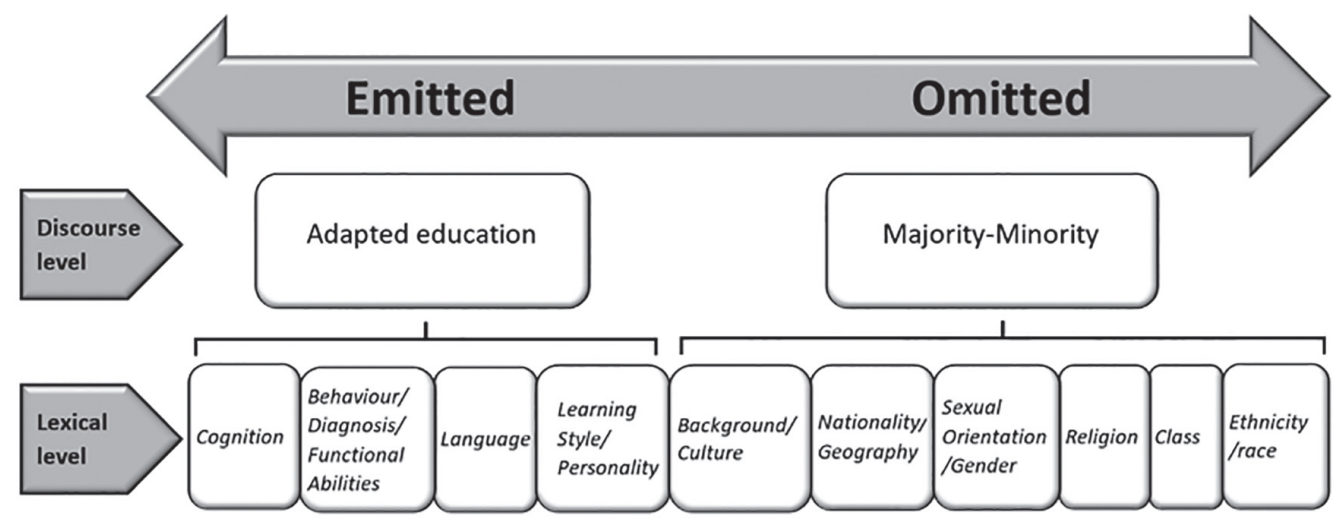

Model II. Emitted and omitted discourses.

\section{The Adapted Education Discourse}

Teachers use of diversity indicators is manifested in the core educational principle of Adapted Education. ${ }^{5}$ One teacher defines it as the "practical representation for diversity". This discourse mainly builds on some of the discourse categories, namely cognitive, behaviour and diagnoses and language, as shown in the following excerpt:

A few students have some difficulties with attending school. Some of them have various challenges, whom we facilitate extra for. [...] we have a new student from Africa, who does not speak Norwegian, to whom we facilitate.

Here, the difficulties and challenges refer to behavioural, cognitive and language diversity explicitly and diagnosis implicitly. Cognitive diversity is the primary factor teachers accommodate when planning lessons, particularly for students they describe as "below average". In this discourse, classroom behaviour is also given much attention, primarily inappropriate or interfering behaviour (often connected to different diagnosis (mainly ADHD)).

In the above excerpt, language connects to a newly arrived student (geographical affiliation) who not yet possess the Norwegian language. Teachers report that they focus more on teaching concepts to ensure that all students follow the lessons. Many point to language as a resource (especially in second language subjects). On the other hand, language, or more specific, other languages than Norwegian, are often referred to as a challenge (like this excerpt) and, in other examples, as a barrier to learning subject matters. Although both students' academic and social aspects are lifted as important, the diversity categories connected to learning are forefronted in this discourse (cognitive, behaviour, diagnosis, and language).

5 The Norwegian educational principle of 'tilpasset opplæring' points to both teaching and learning. 


\section{B. Haugen}

Throughout this discourse, teachers draw on several diversity categories to indicate student's distinctiveness, individual and diverse traits. They are used to indicate how students are unique. One teacher puts it this way: "they are all so different [...] different backgrounds, that can be so very unalike from student to student". Individual needs and how these respective needs must be taken into consideration in education are given great prominence. One teacher says, "We have many ways of learning [and] many ways of being". Teachers also emphasise the importance of catering to the student's needs within the classroom and the form.

\section{The Majority-Minority Discourse}

The Majority-Minority Discourse is placed as omitted in the model because of its sparsity. Minority is manifested both explicitly and implicitly in language. In the emitted discourse of Adapted Education, the citation shows minority language is implied through a negative "does not speak Norwegian" and manifested as a challenge. However, a few other teachers express how they try to incorporate students' language competence in their lessons, most notably in language subjects. An example of this is a teacher who emphasised her need to know of her students "mother tongue" to use as a point of departure in learning a third language. She expresses the wish to accommodate "teaching English based on their mother tongue, or [the language] they have the most confidence. I think that is important". This teacher stress that the students need "to know that [...] their mother tongue is as crucial as Norwegian, in learning a third language." She is not the only one talking about bringing multiple language competence into teaching in this way. However, surprisingly few talks about students first or home languages and first language education ${ }^{6}$ specifically. It is primarily mentioned as a mean to an end: appropriate competence in Norwegian or a third language.

The Majority-Minority Discourse is also apparent in how students are placed in connection to nationality, geography, background, class, and ethnicity. In the following citation, a teacher is describing the constituency and the form:

Compared to other schools, we are in an area that is... very homogenous... in terms of background, class, most of it as I understand it. We have, in a sense, many "similar" children. In the sense that they... anyway, it is a... yes... I do not know how deeply to go into it, but it is a demanding group, in terms of... lots of behaviour...

Several things are noteworthy in this utterance. Although neither mentioning minority nor majority, these positions are implicit. The teacher starts to say something about the constituency and points to background and class, suggesting the students comes

\footnotetext{
6 First language education is in Norwegian called 'morsmålsopplæring' (mother tongue education). 'Minority language background' is a legal category in the Norwegian education system (Burner \& Biseth, 2016) that may grant specific rights to enhanced language support in Norwegian and/or the first/home language.
} 
from families with comparable sociocultural factors. He proceeds to note that "most of it" is "homogenous". It is implied that the form can be described in additional ways in which they are alike. He amplifies this again with "we have, in a sense many "similar" children". In the following sentence, he is about to elaborate on how the form is similar, but pauses. In this silence, he seemingly changes his mind. The adverb and discourse marker anyway can be interpreted as a pointer to end the subject. $\mathrm{He}$ moves the conversation onto behaviour instead. The use of "similar children" and "homogenous area" combined with the "compared to other schools" suggest that other schools have additional diversity this school do not. Other teachers also bring up the notion of homogeneity: "I think it is a rather homogeneous student body, compared to what I am used to. But that might be because I am used to seeing diversity, very distinctly". In this instance, visible diversity traits are commented on directly, indicating skin colour.

\section{Discussion}

The analysis points to some emergent patterns in teachers' reflections on diversity, presented through two discourses. There are three main points I want to discuss. Firstly, I want to address the Adapted Education Discourse. Adapted education is a national political principle and instrument often used to meet changing conditions and goals, typically inclusion, counteracting social reproduction and increased learning outcomes (Jenssen \& Lillejord, 2009). It is a principle, like many other concepts in education, also critiqued for its vagueness. The discourse of Adapted Education as described in this research can point to "adapted education as individualisation" (Jenssen \& Lillejord, 2009). In several instances, the discourse points to manifestations of compensatory strategies for perceived deficits or challenges, most notably the language deficit. The Norwegian language's hegemonic position can put every student who does not have Norwegian as a first language in a deprived position. Language, or more specific, other languages than Norwegian, is referred to as a challenge for learning subject matters. In this sense, the Norwegian language has precedence over other languages in the teachers' discourses. The three diversity categories cognitive, behaviour and language are, in some instances, also used through a deficit discourse. In other words, some students lack something, i.e., sufficient cognitive levels, preferred classroom behaviour, and Norwegian language (e.g. Gorski, 2008, 2011; Valencia, 2010, 2012). If used uncritically, such notions can have severe repercussions for students. It should be noted here, however, that some teachers have more prominent resource perspectives on language and emphasise the importance of utilising students' language competencies.

Secondly, the omittance of minority and majority positions in the discourse production is noteworthy to see in connection with avoidance. As described in the findings,

\footnotetext{
${ }^{7}$ The quotation mark is the teachers own use of air quotes during the interview.
} 


\section{B. Haugen}

teachers seem to avoid some concepts regarding diversity and opt out of diversity concepts relating to visible diversity determinators. They instead point to nationality and language, sexual orientation or gender expressions, and religion throughout the interviews. Bonilla-Silva (2002) and Gullestad (2005) both address the notion of avoidance in their analysis of discourses about race. Gullestad (2004) found that 'skin colour' was used more than 'race' in the Norwegian context. Ten years later, Harlap and Riese (2014) argued that both race and ethnicity are taboo categories due to the strong connotations of eugenics and biology. However, substantial research claims that race and ethnicity are manifested through other utterances, still establishing these categories presence (Bhabha, 2012; Bonilla-Silva, 2015; Goldberg, 1993b; Harlap \& Riese, 2014; Hummelstedt et al., 2021; Said, 2003). Bonilla-Silva (2015) points out that 'race' works without having a discursive space. In my material, teachers appear to indicate ethnicity using language and geography/nationality. In this sense, teachers choose discursive markers which carry the notion of race "behind labels that seem less problematic, such as culture or nationality" (Hummelstedt et al., 2021, p. 2). According to Goldberg (1993b) and Said (2003), nationality and geography are racialised categories of space. I would argue that 'language' and 'minority language' can carry the same connotations. This approach suggests and categorically implies that the ideology of colour-blindness in education covers a hierarchy between races (Harlap \& Riese, 2014). It shows "the disappearance of race in discourse but not in practice" (Bonilla-Silva, 2015, p. 79).

The material suggests that teachers choose to talk about diversity in forms they are comfortable with, i.e., issues affecting learning (like behaviour and learning difficulties) and, to some extent, discrimination in connection to sexual orientation or gender identity. Diversity connected to learning and learning outcome is at the top of the hierarchy of diversity categories teachers use. Unsurprising perhaps, given the curriculum and how these categories are closely related to the teaching profession mandate and other discourses in education. Voicing sexual orientation and gender expressions may be perceived as safer than others, notably race and ethnicity. However, neither the reproduction of hetero-privileges or the continuous marginalisation of non-heterosexuality is critiqued, as Røthing (2009) also found. There are many reasons for teachers' avoidance of notions of race. It can be a strategy to use perceived inclusive language to fulfil the statutory clause of inclusion or to prevent othering. On the other hand, it can also be a strategy to avoid concepts that are unclear (culture) or perceived as directly racialised (ethnicity and skin colour), as Bonilla-Silva (2002) suggests. Bonilla-Silva (2002) connects this strategy to political correctness and the post-civil rights era.

The third issue I want to discuss, is how the two discourses work combined. The emphasis on adapted teaching and individual perspective, with the avoidance of the minority-majority discourse, can mean teachers overlook the possibility to see privilege and structural inequality. By avoiding race, ethnicity, and other concepts that can shed light on majority privilege and minority under-privilege, the intention 
of inclusion can instead lead to the conservation of monocultural practices. In this sense, the majority-perspectives are seen as neutral and universal and result in "white privilege pedagogy" (Levine-Rasky, 2010). Gullestad (2004) reminds us that discourses and interpretations of difference are not natural, neutral, or universal:

but emerge in historically specific processes as human beings give meaning to what goes on around them. When some physical features appear as particularly visible, this is not only due to the features themselves, but to historically specific frames of interpretation that have become self-evident and self-explanatory for many people. Visibility, in the sense of prominent features that are invested with particular meanings, is not natural and universal but is historically specific and culturally produced and reproduced through fleeting and shifting negotiations. (Gullestad, 2004, p. 186)

Teachers' avoidance of visible physical features can be seen to reset, change or transfer the historical and social order, that is, the continuance of reproducing hierarchies of races. However, changing the name or avoiding an issue does not make it disappear. Other researchers also advocate for unveiling the concept of race and ethnicity in education (Chinga-Ramirez \& Solhaug, 2014; Dowling, 2017; Lindquist \& Osler, 2016) to gain suitable pedagogical tools and approaches to structural inequalities and asymmetrical power relations. These opportunities can be lost when teachers fail to consider their own and students racial backgrounds through colour-blindness if continually ignored (Milner, 2010). Educators need to recognise the blindness they (we) carry to our position as majority, and "adopt a reflexive voice, critical of unexamined assumptions” (Gullestad, 2004, p. 182).

\section{Time to admit privilege, race, and power?}

I have pointed to a division in discourses on diversity between what is said and what is not said. Teachers connect diversity, first and foremost, to learning and learning outcome in the Adapted Education Discourse, a discourse that is mainly connected to learning at the individual level. The Majority- Minority Discourse, is to a large degree, omitted from the material and seen as avoidance of uncomfortable issues. As a result, some critical aspects of diversity are left out of the learning equation. In the findings chapter difference was illustrated through the metaphor of 'the heavy backpack' children bring with them to school. The content of this backpack is only revealed through establishing connections with the individual students. There is, however, and additional backpack that needs acknowledgement as well. In 1989, Peggy McIntosh wrote an essay on white privilege, exemplifying hidden advantages, white people experience because of skin-colour, that we carry in our 'invisible knapsack'. Accomplishing equality and equity in education (and society at large) is impossible if we cannot 'unpack the invisible knapsack' of undeserved systemic advantage, in a society designed for the majority. We need to acknowledge that 'race' can work in 


\section{B. Haugen}

two directions, and bring majority-privilege and, consequently minority-underprivilege. It is time to admit privilege, race, and power to have socially just educational practices.

\section{Author biography}

Ingvild Bjørkeng Haugen is a Doctoral Research Fellow in Pedagogy at the Western Norway University of Applied Science, campus Bergen. She has her Bachelor and Master's degree in Education (Pedagogikk) from the University of Bergen. Haugen has worked at the Department of Pedagogy, Religion and Social studies since 2012, and is a member of the research group Diversity and Integration at her institution.

\section{References}

Ahmed, S. (2007). The language of diversity. Ethnic and Racial Studies, 30(2), 235-256. https://doi.org/10.1080/ 01419870601143927

Bhabha, H. K. (2012). The location of culture. Routledge.

Biesta, G. (2005). Against learning: Reclaiming a language for education in an age of learning. Nordisk pedagogik, 25(1), 54-66.

Blackmore, J. (2006). Deconstructing diversity discourses in the field of educational management and leadership. Educational Management Administration $\mathcal{E}$ Leadership, 34(2), 181-199. https://doi.org/10.1177/ 1741143206062492

Blossing, U., Imsen, G., \& Moos, L. (2014). Nordic schools in a time of change. In U. Blossing, G. Imsen, \& L. Moos (Eds.), The Nordic education model. A school for all encounters neo-liberal policy (pp. 1-14). Springer.

Bonilla-Silva, E. (2002). The linguistics of color blind racism: How to talk nasty about Blacks without Sounding "racist". Critical Sociology, 28(1-2), 41-64. https://doi.org/10.1177/08969205020280010501

Bonilla-Silva, E. (2015). More than prejudice: Restatement, reflections, and new directions in critical race theory. Sociology of Race and Ethnicity, 1(1), 73-87. https://doi.org/10.1177/2332649214557042

Borchgrevink, T., \& Brochmann, G. (2008). Mangfold uten grenser [Diversity without limitations]. Samtiden, 3, 22-31.

Burner, T., \& Biseth, H. (2016). A critical analysis of an innovative approach: A case of diversity in Norwegian education. SAGE Open, 6(4), 1-11. https://doi.org/10.1177/2158244016680689

Burner, T., Nodeland, T. S., \& Aamaas, A. (2018). Critical perspectives on perceptions and practices of diversity in education. Nordic fournal of Comparative and International Education, 2(1), 3-15. https://doi.org/10.7577/ njcie. 2188

Chinga-Ramirez, C. (2017). Becoming a "foreigner": The principle of equality, intersected identities, and social exclusion in the Norwegian school. European Education, 49(2-3), 151-165. https://doi.org/10.1080/1056 4934.2017.1335173

Chinga-Ramirez, C., \& Solhaug, T. (2014). Jeg er annerledes!-en diskusjon av erfaringer med å være annerledes i den norske skolen [I'm different!- a discussion of experiences of being different in Norwegian education]. In K. Westrheim \& A. Tolo (Eds.), Kompetanse for mangfold [Competence for diversity] (pp. 217-242). Fagbokforlaget.

Dowling, F. (2017). «'Rase' og etnisitet? Det kan ikke jeg si noe særlig om - her er det 'Blenda-hvitt'! Lærerutdanneres diskurser om hvithet, 'rase’ og (anti)rasisme. [“Race’ and Ethnicity? That, I Cannot Say Anything in Particular About - Here, All Is 'Snow White'» Teacher educators discourses of whiteness, 'race' and ethnicity]. Norsk pedagogisk tidsskrift, 101(3), 252-265. https://doi.org/10.18261/issn.1504-2987-201

Eberly, J. L., Rand, M. K., \& O’Connor, T. (2007). Analyzing teachers' dispositions towards diversity: Using adult development theory. Multicultural Education, 14(4), 31-36.

Fairclough, N. (2003). Analysing discourse: Textual analysis for social research. Routledge. 


\section{Emitted and omitted discourses on diversity}

Fairclough, N. (2013). Critical discourse analysis: The critical study of language (2nd ed.). Taylor \& Francis.

Fylkesnes, S. (2018). Whiteness in teacher education research discourses: A review of the use and meaning making of the term cultural diversity. Teaching and Teacher Education, 71, 24-33. https://doi.org/10.1016/ j.tate.2017.12.005

Fylkesnes, S. (2019). Patterns of racialised discourses in Norwegian teacher education policy: Whiteness as a pedagogy of amnesia in the national curriculum. Fournal of Education Policy, 34(3), 394-422. https://doi.org/ $10.1080 / 02680939.2018 .1482503$

Garthus-Niegel, K., Oppedal, B., \& Vike, H. (2015). Semantic models of host-immigrant relations in Norwegian education policies. Scandinavian fournal of Educational Research, 60(1), 48-71. https://doi.org/ 10.1080/00313831.2014.996593

Goldberg, D. T. (1993a). Racism, the city and the state. Blackwell.

Goldberg, D. T. (1993b). Racist culture: Philosophy and the politics of meaning. Blackwell.

Gorski, P. C. (2008). Good intentions are not enough: A decolonizing intercultural education. Intercultural Education, 19(6), 515-525. https://doi.org/10.1080/14675980802568319

Gorski, P. C. (2011). Unlearning deficit ideology and the scornful gaze: Thoughts on authenticating the class discourse in education. Counterpoints, 402, 152-173.

Gullestad, M. (2002a). Det norske sett med norske øyne. Kritisk analyse av norsk innvandringsdebatt. [The Norwegian seen through the Norwegian gaze. A critical analysis of the Norwegian immigration debate]. Universitetsforlaget.

Gullestad, M. (2002b). Om å være både norsk og "farget». [To be both Norwegian and «Coloured»]. Nytt Norsk Tidsskrift, 19(2), 155-175.

Gullestad, M. (2004). Blind slaves of our prejudices: Debating 'culture' and 'race' in Norway. Ethnos, 69(2), 177-203. https://doi.org/10.1080/0014184042000212858

Gullestad, M. (2005). Normalising racial boundaries. The Norwegian dispute about the term 'neger'. Social Anthropology, 13(1), 27-46. https://doi.org/10.1111/j.1469-8676.2005.tb00118.x

Harlap, Y., \& Riese, H. (2014). Hva skjer når vi ser farge innen utdanning? Mulighetene ved å teoretisere rase i skolen i et "fargeblindt" Norge. [What happens when we see colors in education? Theorizing race in schools in a "colorblind” Norway]. In K. Westrheim \& A. Tolo (Eds.), Kompetanse for mangfold. [Competence for diversity]. Fagbokforlaget.

Hatch, J. A. (2002). Doing qualitative research in education settings. State University of New York Press.

Haug, P., \& Bachmann, K. (2007). Mangfold, individ og fellesskap. [Diversity, individual and community]. In J. Møller \& L. Sundli (Eds.), Leringsplakaten. Skolens samfunnskontrakt (pp. 63-85). Høyskoleforlaget.

Hauge, A.-M. (2014). Den felleskulturelle skolen. [The Common Cultural School]. Universitetsforlaget.

Haugen, C. R. (2012). Ulikhetens kompleksitet - makt over utdanning i kritisk utdanningsteori. [The complexity of diveristy- power and education in critical educational theory]. Norsk pedagogisk tidsskrift, 96(5), 337-347.

Hilt, L. T. (2015). Included as excluded and excluded as included: Minority language pupils in Norwegian inclusion policy. International fournal of Inclusive Education, 19(2), 165-182. https://doi.org/10.1080/136 03116.2014 .908966

Hovdenak, S. S., \& Stray, J. H. (2015). Hva skjer med skolen? En kunnskapssosiologisk analyse av norsk utdanningspolitikk fra 1990-tallet og frem til $i$ dag. Fagbokforlaget.

Hummelstedt, I., Holm, G., Sahlström, F., \& Zilliacus, H. (2021). 'Refugees here and Finns there'-categorisations of race, nationality, and gender in a Finnish classroom. Intercultural Education, 1-15. https://doi.org/10.1080/ 14675986.2020 .1851174

Janks, H. (1997). Critical discourse analysis as a research tool. Discourse: Studies in the Cultural Politics of Education, 18(3), 329-340. http://dx.doi.org/10.1080/0159630970180302

Jenssen, E., \& Lillejord, S. (2009). Tilpasset opplæring: politisk dragkamp om pedagogisk praksis. [Adapted Teaching: Political Struggle for Pedagogical Practice]. Acta Didactica Norge, 3(1).

Jørgensen, M. W., \& Phillips, L. (1999). Diskursanalyse som teori og metode. [Discourse analysis as theory and method]. Roskilde Universitetsforlag.

Kvale, S., \& Brinkmann, S. (2009). Det kvalitative forskningsintervju. [The qualitative research interview]. Gyldendal Akademisk.

Laclau, E. (2005). On populist reason. Verso.

Levine-Rasky, C. (2010). Framing whiteness: Working through the tensions in introducing whiteness to educators. Race ethnicity and education, 3(3), 271-292. https://doi.org/10.1080/713693039 


\section{B. Haugen}

Lillejord, S. (2003). Ledelse i en lcerende skole. [Leadership in a learning school]. Universitetsforlaget.

Lindquist, H., \& Osler, A. (2016). Navigating race and ethnicity in research: Working with Norwegian schools. Race Equality Teaching, 33(3), 12-18. https://doi.org/10.18546/RET.33.3.04

Lund, A. B. (2018). En studie av læreres forståelse av mangfoldsbegrepet. [A study of teachers understanding of the diversity concept]. Nordisk tidsskrift for pedagogikk og kritikk, 4, 87-102. https://doi.org/10.23865/ ntpk.v4.608

Milner, H. R. (2010). What does teacher education have to do with teaching? Implications for diversity studies. Fournal of Teacher Education, 61(1-2), 118-131. https://doi.org/10.1177/0022487109347670

Morken, I. (2009). Mangfold, inkludering og minoritetshierarki i nasjonale læreplaner. [Diversity, inclusion and minority hierachy in the national curricula]. In E. L. Dale (Ed.), Lareplan $i$ et forskningsperspektiv [Curriculum in a Research Perspective] (pp. 155-186). Universitetsforlaget.

Møller, J. (2007). Educational leadership and a new language of learning. International fournal of Leadership in Education, 10(1), 31-48. https://doi.org/10.1080/13603120600933741

Neumann, I. B. (2001). Mening, materalitet, makt. [Meaning, materialism, power]. Fagbokforlaget.

Norwegian Ministry of Education and Research. (2004). Meld. St 30 Culture for learning. Oslo.

NOU 2015: 8. (2015). The school of the future - renewal of subjects and competences. Ministery of Education and Research. https://www.regjeringen.no/en/dokumenter/nou-2015-8/id2417001/

Nyléhn, J., \& Biseth, H. (2015). En utvidelse av begrepet “mangfold”. [An expansion of the term "diversity”]. Norsk pedagogisk tidsskrift, 99(03-04).

Patton, M. Q. (2002). Qualitative research E evaluation methods (3rd ed.). Sage

Pihl, J. (2015). Epistemological and methodological challenges. In B. Sheri \& B. H. Halla (Eds.), Youth 'At the Margins' (pp. 41-63). Sense Publishers.

Robinson, C. C., \& Clardy, P. (2011). It ain't what you say, it's how you say it: Linguistic and cultural diversity in the classroom. Fournal of Cultural Diversity, 18(3).

Røthing, Å. (2009). "Vi har ikke noe imot de homofile" Heteroprivilegier i undervisning om homoseksualitet i norsk skole. ["We do not have anything against the homosexuals" Hetero privileges in teachring about homosexuality in Norwegian Education]. Tidskrift för genusvetenskap, 1.

Røthing, Å., \& Bjørnestad, E. (2015). Kompetanse for mangfold. [Competence for diversity]. Norsk pedagogisk tidsskrift, 99(03-04), 163-167.

Said, E. W. (2003). Orientalism. Vintage.

Sejersted, F. (2005). Sosialdemokratiets tidsalder-Norge og Sverige I det 20. århundre. [Social democratic era Norway and Sweden in the 21st century]. Pax.

Skedsmo, G., \& Mausethagen, S. (2017). Nye styringsformer i utdanningssektoren-spenninger mellom resultatstyring og faglig-profesjonelt ansvar. [New forms of management in educartion- tensions between performance management and professional responsibility]. Norsk pedagogisk tidsskrift, 101(02), $169-179$.

Skrefsrud, T.-A. (2014). Between rhetoric and reality: How diversity was dismissed from curriculum. The International Fournal of Education for Diversities, 3, 87-100.

Skrefsrud, T.-A., \& Østberg, S. (2015). Diversitet i lærerutdanningene - bidrag til en profesjonsorientert forståelse av fag og kunnskapsområder. [Diversity in teacher education programs - contributions for a profession oriented understanding of subjects and fields of knowledge]. Norsk pedagogisk tidsskrift (03), 208-219.

Statistics Norway. (2020, 9. mars 2020). Innvandrere og norskfødte med innvandrerforeldre. [Immigrans and Norwegian-born to immigrant parents]. https://www.ssb.no/befolkning/statistikker/innvbef

Telhaug, A. O., Mediås, O. A., \& Aasen, P. (2006). The Nordic model in education: Education as part of the political system in the last 50 years. Scandinavian fournal of Educational Research, 50(3), 245-283.

Thagaard, T. (2003). Systematikk og innlevelse. En innføring $i$ kvalitativ metode. [Systematics and sensitivity. An introduction to qualitative method] (2nd ed.). Fagbokforlaget.

Valencia, R. R. (2010). Dismantling contemporary deficit thinking: Educational thought and practice. Routledge.

Valencia, R. R. (2012). The evolution of deficit thinking: Educational thought and practice. Routledge. 
Westrheim, K. (2004). Kritisk pedagogikk og multikulturalisme i lys av Freiretradisjonen. Noen sentrale perspektiv. [Critical pedagogies and multiculturalism in light of Freire. Some sentral perspektives]. Nordic Studies in Education, 24(03).

Westrheim, K., \& Hagatun, K. (2015). Hva betyr "kompetanse for mangfold" i utdanningssystemet? Et kritisk perspektiv på mangfolddiskursen. [What does "competence for diversity" mean in the educational system? A critical perspective on the discourse of diveristy]. Norsk pedagogisk tidsskrift, 99(03-04), 168-180.

Wetherell, M., Taylor, S., \& Yates, S. J. (2001). Discourse as data: A guide for analysis. Sage.

Willig, C. (2008). Discourse analysis. In J. A. Smith (Ed.), Qualitative psychology. A practical guide to research methods (pp. 160-185). Sage.

Wodak, R., \& Meyer, M. (2002). Methods of critical discourse analysis. Sage.

Åberg, I. B. (2020). Diversity is the others: A critical investigation of 'diversity' in two recent education policy documents. Intercultural Education, 1-16. https://doi.org/10.1080/14675986.2019.1702294 